\title{
Copyright Dot Com: The Digital Millennium in Copyright
}

\author{
Dr. Robert N. Diotalevi, Esq., LL.M. \\ Director of Legal Studies \\ The College of West Virginia \\ An Affiliate of West Virginia University \\ Beckley, WV \\ E-mail: diotalev@cwv.net
}

\begin{abstract}
With advanced technology come new legal issues. The age of information has given rise to greater concerns about copyright legalities. As new interpretations emerge from Congress as well as the courts, these thorny matters will be at the forefront. Copyright law ultimately affects anyone interested in higher education.
\end{abstract}

Today the Internet, once a research project, is our largest computer system. The Information Super Highway offers a variety of useful information as one navigates down its maze of URLs, browsers and hyperlinks.

The latest Clinton Administration measure, The Digital Millennium Copyright Act, is a massive complexity of rules and regulations. It will probably serve as a challenge for copyright aficionados, service providers and all involved in the field for some time to come.

This work attempts to address the above issues as well as to explore new concerns in copyright.

\section{KEYWORDS}

ALN, Copyright, Internet, Law, Legal

\section{THE LAW OF COPYRIGHT}

\section{A. The Basics}

\section{Overview}

Copyright law is at the heart of everything we do as educators. This has never been more evident than with the emergence of the Internet as a teaching tool. The Internet was once a research project. Today it is the greatest computer system in the world. Also known as the net or cyberspace [1], this information super highway offers a tremendous amount of material. The information age has created greater concerns about copyright law. Many legal courses concerning the Internet are being offered, e.g., Internet Law at Seattle University School of Law, Cyberlaw at The University of California (Berkley), A Law of Cyberspace? at John Marshall Law School, Law and the Internet at Carleton University, Cyberspace Law 1997 at Lewis and Clark College and Law and Internet Seminar at The University of Miami School of Law. Although we are heading into a new millennium, we need to address fundamental areas so vital 
to educators, business people, computer professionals and the like before traveling too far into our future. The survey below represents a random polling of 72 members of Asynchronous Learning Networks (ALN) of Vanderbilt University in Nashville, Tennessee, May 1999. The ALN Center maintains a web site at http://www.aln.org as well as offers workshops, chats and labs on a variety of web-based learning tools. The survey's goal was to elicit responses from those educators who are involved with ALNs as well as affected by issues of copyright law. Its primary focus was to determine members' knowledge of the subject as well as concerns. Individuals were e-mailed an informational form and asked to answer three questions cited below.

There were many interesting and challenging comments. Many members were especially concerned about copyright law regarding electronic or online issues. Most felt that the law is unclear in this respect. Fair use was also at the center of many remarks. And most cited as one of the major problems the controversy surrounding the ownership of faculty-generated materials.

\section{ALN Survey}

Total Responses: 25/72 (34.7\%)

\begin{tabular}{|c|c|c|}
\hline \multicolumn{3}{|c|}{ (1) Knowledge of Copyright Law: } \\
\hline Little & Some & Much \\
\hline $35 \%$ & $65 \%$ & $0 \%$ \\
\hline \multicolumn{3}{|c|}{ (2) Copyright Issues Important to Your Profession: } \\
\hline Online & yright issues & $30 \%$ \\
\hline Instruc & naterilas & $22 \%$ \\
\hline Educat & & $17 \%$ \\
\hline Examp & is of copyrights & $8 \%$ \\
\hline Permis & /holders issues & $4 \%$ \\
\hline \multicolumn{3}{|c|}{ (3) Copyright Issues YOu Would Like to See Addressed: } \\
\hline Copyri & guidelines & $30 \%$ \\
\hline Online & yright issues & $22 \%$ \\
\hline Online & & $22 \%$ \\
\hline Instruc & naterials & $17 \%$ \\
\hline Educat & & $17 \%$ \\
\hline Faculty & intellectual property & $13 \%$ \\
\hline Future & & $8 \%$ \\
\hline Copyri & of terms & $4 \%$ \\
\hline
\end{tabular}

Table 1. ALN Survey of Copyright Issues.

\section{Myths of Copyright}

There are many misconceptions about copyright law. For example, many believe that one needs to provide notice in order to possess a copyrighted work [2]. Some think that registration is necessary or that photocopying requires express permission from the author in all cases. Also mistakes abound as to the defense of copyrights as well as thoughts of the dreaded "copyright 
police" coming to arrest against alleged infringement violations [3]. Copyright law is simply misunderstood.

There is no physicality to copyright protection. A copyright is a type of intellectual property, that is, an attachment of intangible rights occurs when certain rules are followed. It is reminiscent of our federal or state constitutional protections. For example, even though a constitution could burn in a fire we would not lose the fundamental freedoms contained therein. A closer examination reveals that there are several privileges afforded by copyright law.

\section{What is a Copyright?}

There are numerous authors who have addressed this subject [4], [5], [6]. The reason is that copyright has been around for most of our country's existence. In fact, the fundamental basis of copyright law stems from the United States Constitution. In Article 1, Section 8, clause 8 we find that the founding fathers wished to promote science and the useful arts by securing an exclusive right to writings. Unfortunately, the fathers did not explain themselves. Perhaps the most important statute in the area of copyright is the Copyright Act of 1976 (The Copyright Act) [7]. It provides the basic framework for all of our present statutes.

Section 106 of the Copyright Act provides the owner of a copyright certain exclusive rights. In general they include five safeguards:

1) Reproduction of the copyrighted work,

2) Preparation of derivative works (adaptations) based upon the copyrighted material,

3) Distribution of the work,

4) Performance of the work publicly and

5) Displaying of the work publicly [8], [9].

Copyright is a legal device. One must carefully examine several factors in order to determine whether or not copyright law is applicable. Note that copyright law, for the most part, is federal in nature. The laws of other countries must be respected. This work will not address foreign jurisdictional matters apart from the Berne Convention, but will primarily address the laws of the United States while making reference to certain treaties and related concepts.

\section{Originality}

A major requirement in copyright law is that the work be original in order to have copyright protection [10], [11], [12]. The work must be independently conceived by its creator. In Feist, the U.S. Supreme Court explained that the primary objective of copyright law is "not to reward the labor of authors, but [t]o promote the Progress of Science and useful Arts. .." [11]. The case involved the determination of lack of originality in printed, white phone directory pages. However the test is not one of newness. For example, assume a teacher in Orlando writes an article called "Understanding Copyright Law." Another teacher in Omaha has just completed a very similar article with the same name. Neither knows of the other's efforts. Both instructors have created an original work; hence copyright protection is afforded to each of them. Courts would of course look very closely at works that seem to mirror others or outright copy them verbatim as the likelihood of violation is more clear in these circumstances.

\section{Expressions and Fixation}

A key factor is expression. All authors, including those online, must be aware that copyright law affords protection to expressions rather than ideas [13], [14], [15]. Several works that do not enjoy such afforded protection include titles, names, slogans, symbols, designs, lettering, 
coloring, improvisational speeches, unrecorded performances, concepts, devices, systems, methods and calendars. Many times other legal protections such as trademark, trade name and patent come into play. Examples of copyrightable material include original, tangible forms of poetry, literature, motion pictures, sound recordings, computer programming, music, videos, plays, photographs, drawings and the like. The work also needs to be fixed. It is so when its embodiment is sufficiently permanent or stable to permit it to be perceived, reproduced, or otherwise communicated for a period of more than transitory duration. A work consisting of sounds, images, or both, that are being transmitted, is 'fixed' for purposes of this title if a fixation of the work is being made simultaneously with its transmission [16].

Just about any form of original expression qualifies as a tangible medium. This includes a computer's random access memory (RAM) as well as notes hurriedly penned upon the back of a table napkin. When dealing with cyberspace we need to address a multitude of items (such as downloading or copying onto discs and hard drives). Care must be taken to avoid activities that may constitute a violation of fixed, tangible expressions covered by copyright law (see section III of this document) [15 (p. 10-11)]. These would include copying and/or using someone's work outright but the problem is that copyright takes so many different forms. For example, it is arguable that downloading constitutes copying and may very well be an infringement in itself. Also, the faxing of a document qualifies as copying. However, most also agree that mere transmission is not fixation [17]. Case law is sparse in these areas. Nevertheless one thing is certain: The Internet will provide many issues for courts to decide as a result of our advancing technological capabilities. Congress is grappling over bills based on the White Paper [18], [19].

\section{Formalities}

\section{a. Ownership, Registration and Duration}

Ownership rights attach whenever one's expression is fixed in a tangible medium. No other action is necessary to obtain such privileges. Thus, usually the people who create the expression own the copyright thereto, but there are exceptions. For example, if an employee in the course of his or her employment does such a work, the employer owns the copyright of it. Or, if the creator sells the copyright it becomes the property of the business or person who purchases it. Faculty should be careful in reading contracts as well as faculty handbook language that may be incorporated by reference into contractual agreements regarding copyright ownership. There is no controlling case law in this area in light of recent legislation.

It is surprising to most that no major protocol exists to obtain copyright protection. It is no longer necessary to provide notice (discussed later). Registration, however, is advisable. This is the process by which one informs the U.S. Copyright Office of copyright ownership. The Copyright Office provides simple forms [20], [21]. All that is necessary are filing out the paperwork, a twenty-dollar fee and a copy of your expression. Registration assists in protecting one's rights, enjoining others and obtaining statutory and civil remedies. In fact, registration is required in order to bring an infringement suit.

Regarding the length of time that copyright protection lasts on one's work, it normally runs for an artist's lifetime plus fifty years. This year President Clinton signed a measure extending the term an additional twenty years. If the work is for hire, that is, it is done in the course of employment or has been commissioned the copyright lasts between 95 and 120 years, depending on the date of publication. Publication includes sales, leasing, freely giving away and public distribution [22], [23]. 


\section{b. Notice}

Most are familiar with the old copyright notification symbols. They usually contain a $C$ in a circular symbol, or the actual word copyright, with the date and name of the owner.

\section{Example: Copyright (or (C)) 1997 Bill Kane}

In March 1989 the United States joined the Berne Convention for the Protection of Literary and Artistic Works [24]. This multinational treaty provides mutual protection and makes notice symbols obsolete. By joining Berne the United States and member nations recognize and respect each other's laws at least minimally. Again there are advocates of the notice can't hurt rule. It is a possible way of avoiding trouble, but it remains an optional tool at best.

\section{B. The Fair Use Doctrine}

There are several defenses available for those who have allegedly violated copyright. Among these defenses are:

- The work is in the public domain. For example, federal documents are not afforded the protections of copyright law.

- The copyright may be expired, or the holder may have forfeited his or her rights in the work.

- The copyright holder may have granted another permission to use the product.

Fair use [25] is also an exception to normal copyright legalities. It allows, in a limited manner, use of copyrighted protected materials in items for purposes of parody, news reports, comedic acts, research and education. The law considers four factors in determining if fair use is applicable as a defense. They are:

1) the purpose and character of the use, including whether use is of a commercial nature or is for nonprofit educational purposes,

2) the nature of the copyrighted work,

3) the amount and substantiality of the portion used in relation to the copyrighted work as a whole and

4) the effect of the use upon the potential market for or value of the copyrighted work [26, emphasis added] [27].

Fair use is on a case by case basis. The case of Campbell v. Acuff-Rose Music, Inc. [28] demonstrates this. The Court corrected two common lower courts errors. One was to treat the market effect factor as being the most important factor. The other error was to give copyrighted works class treatment by holding, for example, that since the copying of material from one book is infringement, copying from all books is infringement. The Court stressed that simple piracy is to be distinguished from those raising reasonable contentions of fair use. The Supreme Court reversed the Sixth Circuit Court, claiming that it erred in finding copyright infringement against 2 Live Crew. The petitioners were band members Luther R. Campbell, Christopher Wongwon, Mark Ross, and David Hobbs. The group parodied Roy Orbison's "Oh, Pretty Woman" in a song Campbell entitled "Pretty Woman" (see Table 2). After nearly a quarter of a million copies of the recording had been sold, Acuff-Rose sued 2 Live Crew and its record company, Luke Skywalker Records. 


\section{Appendix A}

\section{"Oh, Pretty Woman" by Roy Orbison and William Dees}

Pretty Woman, walking down the street,

Pretty Woman, the kind I like to meet,

Pretty Woman, I don't believe you,

you're not the truth,

No one could look as good as you

Mercy

Pretty Woman, won't you pardon me,

Pretty Woman, I couldn't help but see,

Pretty Woman, that you look lovely as can be

Are you lonely just like me?

Pretty Woman, stop a while,

Pretty Woman, talk a while,

Pretty Woman give your smile to me

Pretty woman, yeah, yeah, yeah

Pretty Woman, look my way,

Pretty Woman, say you'll stay with me

'Cause I need you, I'll treat you right

Come to me baby, Be mine tonight

Pretty Woman, don't walk on by,

Pretty Woman, don't make me cry,

Pretty Woman, don't walk away,

Hey, O. K.

If that's the way it must be, O. K.

I guess I'll go on home, it's late

There'll be tomorrow night, but wait!

What do I see

Is she walking back to me?

Yeah, she's walking back to me!

Oh, Pretty Woman.

\section{Appendix B}

\section{"Pretty Woman" as Recorded by 2 Live Crew}

Pretty woman walkin' down the street

Pretty woman girl you look so sweet

Pretty woman you bring me down to that knee

Pretty woman you make me wanna beg please

Oh, pretty woman

Big hairy woman you need to shave that stuff

Big hairy woman you know I bet it's tough

Big hairy woman all that hair it ain't legit

'Cause you look like 'Cousin It'

Big hairy woman

Bald headed woman girl your hair won't grow

Bald headed woman you got a teeny weeny afro

Bald headed woman you know your hair could look nice

Bald headed woman first you got to roll it with rice Bald headed woman here, let me get this hunk of biz for ya

Ya know what I'm saying you look better than rice a roni

Oh bald headed woman

Big hairy woman come on in

And don't forget your bald headed friend

Hey pretty woman let the boys

Jump in

Two timin' woman girl you know you ain't right

Two timin' woman you's out with my boy last night

Two timin' woman that takes a load off my mind

Two timin' woman now I know the baby ain't mine

Oh, two timin' woman

Oh prettv woman

Table 2. A Comparison of the Two Songs as Cited in the Case's Appendices.

1) The purpose and character of the use was a parody,

2) The nature of the copyrighted song does not prevent commercial use of a parody,

3) The portion used was only the necessary amount, as no more of the lyrics were taken than was necessary in relation to the parodic purpose, and

4) The parody was unlikely to have a large effect on the marketplace [28], [29], [30], [31].

The major problem with fair use is that few courts have addressed academic concerns. Compare Basic Books, Inc. v. Kinko's Graphics Corp., [32] with American Geophysical Union v. Texaco, Inc. [33]. These latter two cases are from the same federal district court with differing results regarding photocopying for education and personal use. And, the latest Clinton administration bill does not clear up this matter either (discussed later). 


\section{Confusing the Issue with $\mathrm{CONFU}$}

In October 1996 The Working Group on Intellectual Property Rights in the Electronic Environment under the Clinton Administration proposed guidelines under CONFU, The Conference on Fair Use. CONFU was initiated in September 1994 and ended May 1997. The U.S. Patent \& Trademark Office hosted the event. Informal talks regarding over twenty topics of interest occurred. No proposals, however, garnered any strong support by participants. CONFU's objective, among others, was to cover fair use in educational settings regarding electronic materials [30], [34].

CONFU offered no guidance concerning online course materials. This subject matter is so new to our legal system that CONFU hardly even addressed it. Instead, CONFU participants decided to let present fair use standards as interpreted by the courts dictate most educational situations. Thus, the problem with CONFU is that it left distance teachers without a clear online strategy.

\section{Fair Use Today}

Fair use is still somewhat convoluted. It is unclear as to what constitutes fair use. This is especially true with the passage of the Digital Millennium Copyright Act (see section IIIB). Also complicating the matter are new and challenging digital advancements. Section 110 (1) of the Copyright Act permits most face-to-face uses. However, copyright holders have exclusive rights to public display and public performance of their works. Table 3 shows some common classroom allowed and disallowed activities gleaned from our current statutes as well as recent case law:

\begin{tabular}{|l|l|}
\hline Permissible Uses & Impermissible Uses \\
\hline $\begin{array}{l}\text { Unlimited, non-dramatic performances of } \\
\text { music or literature (i.e., reading novel } \\
\text { excerpts and musical lines) }\end{array}$ & $\begin{array}{l}\text { Dramatic performances of musicals or } \\
\text { literary works }\end{array}$ \\
\hline $\begin{array}{l}\text { Unlimited displaying of charts, graphs or } \\
\text { photographs, including stills of motion } \\
\text { pictures (distance education included) }\end{array}$ & $\begin{array}{l}\text { Copying coursepacks for class distribution } \\
\text { without meeting fair use criteria for each } \\
\text { material used }\end{array}$ \\
\hline Copying out-of-print-books & Out-of-print book (placement on Web) \\
\hline $\begin{array}{l}\text { Journal article posted to Web page (restricted } \\
\text { access, students and faculty) }\end{array}$ & $\begin{array}{l}\text { Textbook photocopying and placement on } \\
\text { Web (even if password or pin provided) }\end{array}$ \\
\hline $\begin{array}{l}\text { Placement of book on reserve in library } \\
\text { in library }\end{array}$ \\
\hline Showing videotape for classroom instruction & $\begin{array}{l}\text { Copying videotape for classroom instruction } \\
\text { and/or charging fees }\end{array}$ \\
\hline $\begin{array}{l}\text { Broadcast or rebroadcast of classroom } \\
\text { presentation to home or office (including the } \\
\text { showing of another's video if permission is } \\
\text { obtained }\end{array}$ & $\begin{array}{l}\text { Videotaping of classroom (teacher's or } \\
\text { student's presentation }\end{array}$ \\
\hline $\begin{array}{l}\text { Text, video, audio, and/or photographs used } \\
\text { in telecourse for enrolled students }\end{array}$ & \\
\hline $\begin{array}{l}\text { Telecourse via cable television if institution- } \\
\text { controlled audience (i.e., student body) }\end{array}$ & \\
\hline $\begin{array}{l}\text { Remote access of searchable database via the } \\
\text { Internet if institution-controlled audience }\end{array}$ & \\
\hline Student project placed on the Internet with & \\
\hline
\end{tabular}




\begin{tabular}{|l|l|}
\hline restricted access to other students & \\
\hline $\begin{array}{l}\text { Use of commercial, instructional videotape } \\
\text { on cable television or two-way interactive } \\
\text { video }\end{array}$ & \\
\hline $\begin{array}{l}\text { Use of commercial, instructional videotape } \\
\text { on cable television or two-way interactive } \\
\text { video (via Internet, access restricted) }\end{array}$ & \\
\hline $\begin{array}{l}\text { Taping on air television program to be shown } \\
\text { on cable television or via two-way interactive } \\
\text { video (remote sites allowed to record class to } \\
\text { avoid possible technical difficulties) }\end{array}$ & \\
\hline
\end{tabular}

Table 3. Permissible and Impermissible Uses of Copyrighted Material.

There are several cases of note that provide guidance regarding instructional purposes even though they do not directly deal with education. For example, in 1991 the court in Basic Books, Inc. v. Kinko's Graphic Corp. [32] held that a commercial copy shop that copied coursepacks was not entitled to the right of fair use. A similar ruling occurred in 1996 with Princeton University Press v. Michigan Document Services [35]. Photocopying by a for-profit corporation's lab scientist Chickering did not constitute fair use. The Court stated, "(o)ur opinion does not decide the case that would arise if Chickering were a professor or an independent scientist engaged in copying and creating files for independent research" [35]. It is interesting to note that one of the three dissents favored the making of multiple copies by professors in classroom situations. The court did not address the issue [33]. The United States Supreme Court has not addressed this matter either.

To add to the confusion, The Digital Millennium Copyright Act (see section IIIB) does not give us clear guidance as to several issues concerning downloading, posting and web site linkage. Future court decisions as well as study by Congress under the guidelines of The Digital Millennium Copyright Act will be needed to address these matters.

\section{TECHNOLOGY...UNWEAVING THE TANGLED WEB}

\section{A. Overview}

There is little if any judicial guidance in this area so important to educators. Most case law deals with corporate liability regarding copyright infringement such as the NetCom case (see section B3). Some scholars claim that The Internet has provided a type of escape from copyright legalities. In other words, with the emergence of innovative ways of communicating such law is not applicable to the information highway and the statutes and cases are too archaic. This argument has had little effect upon Congress in the consideration of laws. Nor have many in the field given it much if any validity.

\section{B. Distance Learning}

Distance learning refers to the delivery of educational materials that occurs when course instruction is in a non-traditional setting [36]. Examples include audio, video, motion picture, cable television, microwave and, of course, the Internet. Section 107 of the Copyright Act governs educational performances and displays of works. But, performing and transmitting of information are different. Fair use is not helpful and CONFU seems to be silent. Thus, adoption of some solid guidance is in order to give direction in these gray areas. 


\section{Concerns for the Digital Millennium Educator: Institutional Policies and Procedures}

Several institutions have addressed copyright law by implementing measures via hard copy or the Internet [37], [38]. Colleges and universities offer subjects on such intellectual property matters. At The College of West Virginia (CWV) we recently included two Internet courses, entitled Copyright Law and The Law of Cyberspace into our curricula. At conferences nationwide educators have expressed the need for institutions to provide offerings in these areas. There are many excellent resources available to those not familiar with these issues (see Table 4). The most complete resource I have found is by the State Copyright Regents Committee's Office of Legal Affairs at The University of Georgia (see Table 4). It covers such topical areas as research, writing, multimedia projects and video/sound recordings. It does so by a series of questions and answers dealing with everything from unpublished letters to out-of-print books. The site contains wonderful scenarios such as professors who scan articles from copyrighted journals and add them to their web pages, the showing of copyrighted motion pictures for instructional purposes, copying videotapes for classroom instruction and the creation of telecourses utilizing copyrighted materials. And, it gives a good general overview of copyright law. Also, The Copyright Clearance Center has a free handout entitled "Guidelines for Creating a Policy for Copyright Compliance" [39].

\begin{tabular}{|c|c|c|}
\hline University & Notes & URL's \\
\hline University of Georgia & $\begin{array}{l}\text { "The Regents Guide to } \\
\text { Understanding Copyright and } \\
\text { Educational Fair Use" }\end{array}$ & $\begin{array}{l}\text { http://www.peachnet.edu/admin/l } \\
\text { egal/copyright/copy.html } \\
\text { (accessed February 17, 1999) }\end{array}$ \\
\hline $\begin{array}{l}\text { Indiana University-Purdue } \\
\text { University Indianapolis and } \\
\text { Indiana University }\end{array}$ & $\begin{array}{l}\text { The Copyright Management } \\
\text { Center serves both institutions. It } \\
\text { has everything from fair use to } \\
\text { distance education to library } \\
\text { issues and special media issues. } \\
\text { Indiana University offers policies } \\
\text { as well as sample forms for } \\
\text { faculty regarding distance } \\
\text { learning and research } \\
\text { considerations in general }\end{array}$ & $\begin{array}{l}\text { http://www.iupui.edu/ copyinfo } \\
\text { (accessed Jan. 7, 1999) } \\
\text { http://www.indiana.edu/ ufc/circu } \\
\frac{\text { lars/97-98/U16-98.htm }}{\text { http://www.iupui.edu/ copyinfo/r }} \\
\text { aagreemt.html } \\
\text { http://iupui.edu/ copyinfo/dlagree } \\
\text { mt.html }\end{array}$ \\
\hline The University of Texas & $\begin{array}{l}\text { "Guidelines for Classroom } \\
\text { Copyrighting of Books and } \\
\text { Periodicals," adapted from the } \\
\text { Association of American } \\
\text { Publishers and The Author's } \\
\text { League of America. } \\
\text { The University System also has } \\
\text { wonderful copyright presentations } \\
\text { via the Web. } \\
\text { Check out "Copyright Law in } \\
\text { Cyberspace" at the above site } \\
\text { with /nacua.htm finishing the web } \\
\text { address after the } \\
\text { intellectualproperty. } \\
\text { Be sure to visit the copyright }\end{array}$ & $\begin{array}{l}\text { http://www.utsystems.edu/OGC/I } \\
\text { ntellectualProperty/clasguid.htm } \\
\text { (accessed Jan. 7, 1999) } \\
\text { http://www.utsystems.edu/ogc/int } \\
\text { ellectualproperty/present.htm }\end{array}$ \\
\hline
\end{tabular}




\begin{tabular}{|c|c|c|}
\hline & $\begin{array}{l}\text { management information site at } \\
\text { the preceding address, ending in } \\
\text { copymgt.htm (accessed 10/98). } \\
\text { Finally, for the beginner, UT has } \\
\text { a great site called "Crash Course } \\
\text { in Copyright" }\end{array}$ & $\frac{\text { http://www.utsystem.edu/OGC/int }}{\text { ellectualproperty/cprtindx.htm }}$ \\
\hline The University of Minnesota & & $\begin{array}{l}\text { http://arl.cni.org/scomm/copyright } \\
\text { /Minnesota.html } \\
\text { (accessed Jan. 7, 1999) }\end{array}$ \\
\hline Rensselaer Polytechnic Institute & Library Policies & $\begin{array}{l}\text { http://www.rpi.edu/dept/library/P } \\
\text { olicies/fairuse.html } \\
\text { (accessed Jan. 9, 1999) }\end{array}$ \\
\hline Brigham Young University & $\begin{array}{l}\text { This must be downloaded as an } \\
\text { MS Word file in order to be read. }\end{array}$ & $\begin{array}{l}\underline{\text { http://www.byu.edu/ ttdata/intell. }} \\
\underline{\text { html }} \\
\text { (accessed Jan. 7, 1999) (dated } \\
\text { 1994) }\end{array}$ \\
\hline $\begin{array}{l}\text { Massachusetts Institute of } \\
\text { Technology }\end{array}$ & $\begin{array}{l}\text { MIT also has a good site } \\
\text { regarding frequently asked } \\
\text { questions on copyright. }\end{array}$ & $\begin{array}{l}\underline{\text { http://web.mit.edu/policies/13.1.h }} \\
\underline{\text { tml }} \\
\text { (accessed Jan. 14, 1999) } \\
\underline{\text { http://web.mit/cwis/copyright/faq. }} \\
\underline{\text { html }} \\
\text { (accessed Jan. 14, 1999) } \\
\text { (dated 1995) }\end{array}$ \\
\hline North Carolina State University & & $\begin{array}{l}\text { http://www.lib.ncsu.edu/issues/T } \\
\text { RLN_mod_copyrt_pol.html } \\
\text { (accessed Jan. 11, 1999) (dated } \\
\text { 1993) }\end{array}$ \\
\hline Columbia University & $\begin{array}{l}\text { "The Educator's Copyright } \\
\text { Survival Guide" site is referred to } \\
\text { as CREDO, "Copyright } \\
\text { Resources for Education Online." }\end{array}$ & $\begin{array}{l}\text { http://www.ilt.columbia.edu/proje } \\
\text { cts/copyright/ILTcopy3.html } \\
\text { (accessed Jan. 10, 1999) }\end{array}$ \\
\hline The University of California & $\begin{array}{l}\text { "Copyright Considerations for } \\
\text { Faculty-Authored Multimedia } \\
\text { Instructional Materials" }\end{array}$ & $\begin{array}{l}\text { http://mody.ucdavis.edu/Distance- } \\
\text { ed/Copyright.htm (accessed Jan. } \\
\text { 10, 1999) (dated 1996) }\end{array}$ \\
\hline Stanford University & $\begin{array}{l}\text { Stanford also has guidelines for } \\
\text { the educator } \\
\text { and the librarian. }\end{array}$ & $\begin{array}{l}\text { http://www.portfolio.stanford.edu } \\
\text { /101242 (accessed Jan. 10, 1999) } \\
\text { http://www.sul.stanford.edu/cpyri } \\
\text { ght.html } \\
\text { http://fairuse.stanford.edu/library }\end{array}$ \\
\hline Yale University & $\begin{array}{l}\text { "Copyright Resources Online" is } \\
\text { a fantastic summary for anyone } \\
\text { interested in these and related } \\
\text { issues. }\end{array}$ & $\begin{array}{l}\text { http://www.library.yale.edu/ oker } \\
\text { son/copyproj.html (accessed Jan. } \\
\text { 10, 1999) }\end{array}$ \\
\hline The University of Tennessee & & $\begin{array}{l}\text { http://toltec.lib.utk.edu/ gco/patc } \\
\underline{\text { oc.html }} \\
\text { (accessed Jan. 19, 1999) (dated } \\
\text { 1994) }\end{array}$ \\
\hline
\end{tabular}




\begin{tabular}{|l|l|l|}
\hline $\begin{array}{l}\text { The University of Canada at } \\
\text { Alberta }\end{array}$ & "Copying Right" & $\begin{array}{l}\underline{\text { http://libits.library.ualberta.ca/libr }} \\
\underline{\text { ary html/copyright/copy_right.ht }} \\
\begin{array}{l}\underline{\mathrm{ml}} \\
\text { (accessed February 11, 1999) } \\
\text { (dated 1994) }\end{array}\end{array}$ \\
\hline The University of Chicago & $\begin{array}{l}\text { "Policy Guidelines for Publishing } \\
\text { Networked Information" }\end{array}$ & $\begin{array}{l}\frac{\text { http://www.uchicago.edu/uofc/ca }}{\text { mpus/policies/publishing- }} \\
\text { policy.html } \\
\text { (dated August 1994) }\end{array}$ \\
\hline
\end{tabular}

Table 4. University Web Resources Addressing Institutional Policies and Procedures.

\section{Web-related Issues}

Concerns exist as to linking to a web site without permission. Such linkage probably would be beneficial to businesses. In other words, the mere provision of access to another's site, as long as no one directly steals, gives credibility and free advertising to the company providing the site. People would be telling others of the organization free of charge. More importantly, there are other issues involving cyberspace that need to be examined.

Most scholars feel that the clear-cut issues will remain the same. In other words, treatment of material on the Web is similar to that of literature. While information on the Web may be protected, it should be noted that copyright protection does not extend to computer systems, processes and the like. Thus, the copyright protections do not cover machinery. Clearly actions such as browsing, e-mailing and related practices seem free of major problems [18 (p. 64-65, n. 2)]. Note that the White Paper indicates browsing is an infringement. Section 110 of The Copyright Act [40] addresses copyrighted works regarding distance education, however, the language of the statute is quite befuddling and needs to be examined carefully. Section 110(2) allows for the "transmission" of a performance or display, but only within defined limits. The code hereby defines "transmit" to mean communicating a performance or display "by any device or process whereby images or sounds are received beyond the place from which they are sent." Note that Section 110(2) allows displays of nearly all works, but it confines the allowed performance to a non-dramatic literary or musical works. Thus, a professor may read a book concerning The Titanic aloud, but showing the movie of the same name is quite another matter. When passed in 1976 Section 110(2) involved only television technology. The waters get even murkier when information is sent via the Internet through multiple transmissions.

\section{The NetCom Case}

In the case of Religious Technology Center v. Netcom On-Line Communications Services Inc. [41], [42] (referred to as NetCom), Netcom found itself ensnarled in a copyright infringement suit. The case centers upon a former Church of Scientology minister, Dennis Erlich. He copied some of the works of L. Ron Hubbard. Erlich then placed them on Usenet. Erlich accessed Usenet via a Bulletin Board Service (BBS). Netcom provided linkage. Plaintiffs Religious Technology Center and Bridge Publications, Inc., sued Erlich as well as the BBS operator, Klemesrud, and the Internet access provider, Netcom. The plaintiffs had informed both Klemesrud and NetCom of the infringement, but they contended that it would be impossible to prescreen Erlich's postings. Furthermore, NetCom stated that removing Erlich from the Internet would mean affecting hundreds of users of Klemesrud's BBS. The case turned on the NetCom's potential liability. The court granted in part and denied in part the plaintiffs' motion for a preliminary injunction against Erlich [42]. In the other opinion [41] the court granted in part and 
denied in part NetCom's and Klemesrud's motions for summary judgment as well as judgment on the pleadings and denied plaintiffs' motion for a preliminary injunction.

Traditionally, as seen in Playboy Enterprises, Inc. v. Frena, [43] copyright infringement has been a "strict liability" offense, i.e., the infringer may be liable for the illegal act even if he neither knew nor had reason to know of it. The plaintiff sued Netcom on three liability theories: direct, vicarious and contributory. The court held that direct liability was inapplicable in that Netcom did not engage in any action that caused a direct violation of copyright law. The company merely created a copy for a third party. The postings resulted in the creation of copies on Netcom's storage devices, but the creation of the copies as well as the distribution and display of them was done without any volitional act [44].

On the issue of vicarious liability the court also stated that plaintiff failed to prove defendant had the requisite control over the infringer's actions sufficient to show any gain from its action [44 (1377)]. However, on the issue of contributory liability the court held there existed evidence that presented a question of fact as to whether Netcom had knowledge and failed to take appropriate action [44 (1369)]. The plaintiff informed Netcom of the infringement. The Court held that failure to take said action equates to substantial participation in these instances resulting in potential liability for the storage of data [44 (1374-5)]. The Court stated that Erlich had infringed, but the case regarding NetCom was ultimately settled out of court in 1996 [44 (1375)], [45], [46], [47], [30].

A link or URL (Uniform Resource Locator) is a destination obviously not copyrightable since it does not represent an expression that is fixed in nature. There is the issue of the accessing of web pages. The problem arises when one saves a page to the hard drive. This action constitutes the making of a copy so copyright law is applicable. The crux of the matter is whether or not there is wrongful reproduction of a fixed expression so as to violate the law. There are those who contend that public domain or fair use standards apply in these instances. Again, the courts will have to deal with this subject matter in the near future. Congress is in the process of studying such matters. The law here is quite unclear.

\section{Permission: The Rule of the Day}

Since copyright law is a bit murky when it comes to issues involving teaching, distance education and the like, obtaining consent is usually in order. It is the best thing to do to ensure legality. For example, whenever materials are being used for commercial or profit purposes, obtaining permission is essential. Most of us forget that educational institutions are here to make money. Organizations charge fees in distance learning. Not only is getting permission proper netiquette but it will save dollars down the road and potential loss of employment for those responsible. When viewing another's work ask the following questions:

1) Does copyright law protect this work?

2) Am I trying to use and copy it for myself as my own work?

3) Does any exception to the law apply (e.g., fair use)?

When in doubt, simply ask permission and, above all, get it in writing.

\section{Legality: Truth or Consequences}

Most educators have never been faced with copyright-related lawsuits for good reason: a cause of action is simply too expensive for the plaintiff to pursue. In the past only a few suits have been filed against faculty. However, there are valid reasons for obedience to the law. Universities and 
colleges bear responsibility of complying with these laws. Most likely they will be the targets of the deep pocket legal action. Even though most unauthorized uses are never litigated, if ever discovered, everyone must be aware of the rules. This is important when it comes to the roles of our employees and teachers of law.

The consequences of copyright violation are housed in an infringement complaint. Along with civil and statutory awards for each violation, criminal penalties could be meted out [48], [49], [50], [25 (p. 26)]. Federal criminal consequences have been revised with the passage of The Digital Millennium Copyright Act (see section IIIB). In the case of cyberspace, if guidance is not effectively dispatched many will find themselves facing legal liability in the future [51]. Penalties are becoming harsher especially with the passage of The Digital Millennium Copyright Act as well as other bills pending in Congress (see section IIIB4).

\section{COPYRIGHT'S FINAL FRONTIER?}

\section{A. Implied License}

The theory of implied license has been bantered around cyberspace [52], [53]. In a case involving the validity of shrinkwrap licenses, agreements by buyers to accept the terms by opening package wrapping. The contention is that permission is automatically granted to those setting up a web page. This idea has been asserted particularly by those involved in hypertext linkage. The plain truth is that this seemingly simple solution is not as simple as it looks. There is no legal precedent regarding implied license. The best advice is for all to exercise caution and clearly acknowledge links to other sites in order to avoid liability [54], [55]. This can be achieved by contacting all known owners and/or citing one's sources as completely as possible.

\section{B. The Digital Millennium Copyright Act 1. Overview}

On October 28, 1998, President Clinton signed a bill providing new game rules for the treatment and respecting of online copyrighted material. The Digital Millennium Copyright Act (DMCA) [56], [57] served as the subject of debate for many interested in copyright law. Both houses of the one hundred and fifth Congress gave it the green light earlier in the month of October [58], [59], [60], [61], [62]. The DMCA adds two new chapters to Title 17 as it strengthens international law worldwide and protects domestic technology. President Clinton released the following statement after passage:

I am pleased that the Congress has passed the Digital Millennium Copyright Act. This bill will implement the two new landmark World Intellectual Property Organization (WIPO) treaties that my Administration negotiated. These treaties will provide clear international standards for intellectual property protection in the digital environment and protect U.S. copyrighted works, musical performances and sound recordings from international piracy. American copyright-based industries that produce and promote creative and high-technology products contribute more than $\$ 60$ billion annually to the balance of U.S. trade. This bill will extend intellectual protection into the digital era while preserving fair use and limiting infringement liability for providers of basic communication services.... [63]. 
The one hundred and fifty-page document divides into five titles (see Table 5).

Note: Except for Title I (Treaty), each the following are effective upon enactment:

Title I: Implementation of two (2) treaties dealing with digital issues, copyright protection and management systems (The WIPO Copyright Treaty Act and the WIPO Performances and Phonograms Treaty)

Title II: Limitation of Online infringement liability for ISPs (Internet Service Providers) (reducing legal uncertainties regarding such items as digital networks, strengthening anti-online piracy, outlining copyright owners' notification procedures, defining university liability, and creating a "safe harbor" for ISPs in four (4) situational activities):

1. Conduits (provision of materials transmission, routing and connections)

2. System Caching (temporary or intermediate materials storage to improve user performance and reduce congestion)

3. User Storage (materials storage on systems or networks at the direction of users)

4. Information Locators (linkage tools by service providers such as directories, pointers and/or hyperlinks to facilitate material access)

Note: 1 and 2: transmission must be initiated by a third party.

3 and 4: requires the ISP to be without knowledge or having reason to know of any infringement, to obtain no direct financial benefit and to not change the materials.

Title III: "The Computer Maintenance Competition Assurance Act" (formerly H.R. 72) (creation of an exception for temporary computer program reproduction in maintenance/repair).

Title IV: "Miscellaneous Provisions" (distance education, exemption for libraries/archives, ephemeral (momentary) recordings).

Title V: "The Vessel Hull Design Protection Act" (formerly H.R. 2696) (creation of new, sui generis protections for boat hull designs, in a new Chapter entitled Chapter 13 of Title 17 of the U.S. Code, effective for two years) [64], [65], [66], [67].

Table 5. Five Titles from the Digital Millennium Copyright Act. 


\section{The DMCA in Depth}

Specifically, the Digital Millennium Copyright Act:

1) Limits copyright infringement liability for Internet Service Providers (ISPs) for the mere transmission of information as a conduit or transient host, provided no knowledge or financial gain is present,

2) Establishes guidelines for the removal by ISPs of material from the Internet that appears to be an infringement upon the knowledge by the ISP,

3) Limits liability against institutions when faculty members use educational facilities in order to publish materials electronically,

4) Makes criminal the circumvention of anti-piracy devices, also known as "little black boxes,"

5) Outlaws code-cracking devices but not ones being employed for research, testing, law enforcement activities and related legal means,

6) States that the fair use doctrine remains a viable defense in copyright infringement matters, but does not go into much detail,

7) Updates the library exemption for facilities to take advantage of digital technology while engaging in activities similar to those for non-digital methodologies,

8) Directs The Register of Copyright to consult with educators, copyright owners and libraries, and to submit recommendations for the promotion of distance education through digital means and

9) Implements two treaties regarding the respecting of copyright laws internationally.

The legislation has significant impact on our international status. Although technically the Senate still must ratify international pacts before governments of the world give credence to the measure, the law does prepare for the ratification and execution of two treaties regarding The World Intellectual Property Organization (WIPO). In December 1996, over one hundred and fifty countries agreed on WIPO at a conference on digital information and copyrights in Geneva. The first treaty addresses digital authors' rights. The second pact focuses upon The Internet and sound recordings. Thirty nations must ratify the agreement for it to be effective globally [68].

Internet service providers, software industry groups, music/movie companies heralded the DMCA, with the support of such leaders as Senator John Ashcroft of Missouri and Representatives Rick Boucher of Virginia, Scott Klug of Wisconsin and Tom Campbell of California. They were particularly gratified with the DMCA affording protection against unscrupulous individuals who could possibly make use of the information super highway for stealing and illegally distributing goods such as software, course materials and websites.

Many applauded the efforts of Congress and the President. Attorney Jonathan Band, a partner in the Washington, D.C., office of San Francisco's Morrison \& Forester, L.L.P, practices copyright law. He states:

The Digital Millennium Copyright Act accomplishes four things... First, it implements the World Intellectual Property Organization treaties, thus harmonizing U.S. copyright law with international law. Second, the DMCA establishes "safe harbors" for online service providers who unknowingly transmit copyrighted works. Third, the act permits the copying of software during computer maintenance. Finally, the DMCA facilitates Internet broadcasting [69]. 
However, members of the academic and research communities have mixed feelings about the measure. Some claim the DMCA would hinder concepts of fair use and other acceptable means of validly utilizing copyrighted materials. Concerns regarding educational use continue as a result. There are those who also cite the measure stifles operation, free thought, expression, system corrections, etc. Most library organizations oppose the measure, stating it does not contain many desired provisions. Specifically, according to Professor Bob Oakley, Library Director of the Georgetown University Law Center, H.R. 2281 is a hindrance to reading, browsing, classroom teaching and application of fair use standards. He claims, "HR 2281, as drafted, would grant copyright owners a new and unrestricted exclusive right to control access to information in digital works which could negate one of the most basic principles...the ability to gain access information in published or publicly available works..." [70].

Among the groups that communicated concerns about the legislation to Congress were:

- The American Association for the Advancement of Science,

- The American Association of Law Libraries,

- The American Association of Legal Publishers,

- The American Historical Association,

- The American Library Association,

- The Digital Future Coalition (DFC),

- The Medical Library Association,

- The Music Library Association,

- The National Education Association,

- The National Humanities Alliance and

- The Association of Research Libraries [71].

For example, among the changes for libraries, Section 108 of The DMCA now allows libraries to make up to three digital archival copies of published and unpublished materials for storage and retrieval. Previously one copy was allowed. However, The DMCA does not provide that these digital copies be made accessible to the public away from library grounds. The copy sent must arrive in analog form. And, any copyright notice originally on a work should be included on the copy. If not, the library must give a legend stating that the work is possibly protected by copyright law.

Perhaps the ideas of many are expressed by The Digital Future Coalition (DFC). The DFC is a forty-two-member organization comprised of non-profit and for-profit entities interested in intellectual property law in the digital era. According to Peter Jaszi, "This legislation is a substantial victory for both the creators and consumers of intellectual property because it provides meaningful protection while recognizing the traditional balance between owners' rights and the privileges of legitimate users" [72].

\section{The New Millennium Institutional Service Provider}

The DMCA clearly does not mandate universities and colleges to become commercial Internet Service Providers (ISPs) or Online Service Providers (OSPs). But, liability may result if institutions allow impropriety over their computer systems. It may very well be advisable to register an agent with The Copyright Office for the receipt of claims regarding potential copyright infringement. Among the schools that have done so are Northeast State Technical Community College in Blountville, Tennessee, The University of Nebraska in Lincoln, Nebraska, UCLA in Los Angeles, California, and The University of Chicago in Illinois. Other facilities are quickly following suit. 
The College of West Virginia has instituted policies specifically covering the Internet and e-mail. They deal with a variety of issues, including but not limited to, software, media services, e-mail usage/transmissions, passwords and privacy. They are designed to inform those utilizing the facilities of potential problems and liabilities that may result from improper usage. The CWV policies include internal investigations, record keeping and the promotion of the college's mission and internal procedures. But some institutions lack proper, effective policies. Colleges and universities need to develop or update procedures for the handling of potential infringement. A major emphasis of these directives should be to have policies clearly stated online as well as around campus. Swift action is necessary for those repeat offenders who abuse the system at the school's expense. A termination of their Internet accounts or other appropriate punitive measures are absolutely crucial. Experienced professionals should effectively carry out implemented policies and notify proper authorities of any mishaps immediately. Most importantly colleges and universities need to institute programs for the understanding and education of all involved in the process.

Again it is extremely difficult to address specific concerns since The DMCA only provides that The Copyright Office consult with affected parties and make recommendations to Congress on how to promote distance education through digital technologies. Among the things that Congress desires in its report are:

- The need for exemptions,

- Categories of works which would be included in an exception,

- Appropriate limitations on portions of works that may be used under any exemptions adopted,

- The parties eligible under exemptions,

- The extent to which use of technological protection measures should be mandated as a condition of eligibility for any exemption,

- The extent to which the availability of licenses should be considered in assessing the eligibility of any exemption and

- Other appropriate issues [73].

At the time this work was being completed Congress had just received the final report from The United States Copyright Office [74], [75], [76]. The Report advises that $\$ 110(2)$ be updated and recommends clarification regarding the term "transmission," that should apply to digital as well as analog. Regarding fair use, the report claims that it is "technology-neutral" and must be defined in explicit language in order avoid further confusion. Thus, if Congress approves the recommendations, the law would let professors teaching classes over the Web at nonprofit institutions show movie clips or play parts of musical recordings.

\section{Criminal Consequences and Liability in the Digital Age}

Plaintiffs recovering successfully for wrongdoing under The DMCA have the choice of illegally obtained profits, statutory damages or injunctive relief. But, the most alarming fact is that copyright infringers can go to jail for violations. According to The Software Publishers Association, copyright piracy costs over eighteen billion dollars worldwide [77], [78]. Regarding damages, on May 11, 1999, Representative James Rogan of California introduced The Copyright Damages Improvement Act of 1999, H.R.1761. Representative Howard Coble of North Carolina, Chairman of the House Intellectual Property Subcommittee, to which the bill was referred, is cosponsoring it. The measure would increase the statutory awards available to copyright owners whose works are infringed. It would also add a new tier of damages that targets parties that have 
engaged in a "repeated pattern or practice of infringement." Finally, the bill contains language to prevent offenders from declaring bankruptcy to avoid paying a copyright infringement judgment against them. The DMCA is filled with penalties as well as liabilities for those tempted to go astray.

In general, The DMCA's Sections 1203 and 1204 impose updated standards and gives guidance for works on The Net especially regarding criminality. It will be unlawful to create or sell any technology used to break copyright protection devices. Illegal circumvention, i.e., those acts that constitute piracy of another's work, will carry statutory damages of twenty-five hundred dollars [78]. And, those committing illegal acts in a willful and purposeful manner will result in serious criminal penalties of several hundred thousand for each violation [79].

Section 1204 provides for violations regarding circumvention of copyright protection systems. Anyone who violates either section for "purposes of commercial advantage or private financial gain" faces up to five hundred thousand dollars in fines or imprisonment of up to five years, or both, for the first offense. The penalty is up to one million dollars and up to ten years, or both, for subsequent offenses [80]. Courts will have the power to award triple damages against repeat offenders. A five-year statute of limitations applies here [80 (1204(c))], [81].

Meantime, acts of illegality regarding the manufacture and distribution of circumvention devices have immediate consequences for perpetrators [82]. The DMCA is weak as to the outlawing of tampering or interfering with safeguards in technology. It focuses more upon copyright management information issues. The DMCA makes it illegal to "manufacture, import, offer to the public, provide or otherwise traffic in any technology, product, service, device, component or part thereof "[82 (1201(a))] that may be used to circumvent a technological protection measure. In other words, any device utilized to thwart copyright protections is illegal. Burglary tools like the infamous black boxes are especially of concern in this regard. The DMCA also bars "the act of breaking through encryption and similar technologies" [83] in order to gain access to copyrighted materials. However, the new law affords protection for the promotion of legally sound endeavors such as encryption research, security testing, law enforcement needs and reverse engineering [84]. Finally, devices to detect and prohibit child pornography on the Internet were given exemption.

\section{CONCLUSION}

This article addresses basic copyright law as well as delves into the administration's latest measure. It details several issues vital to educators in the new, digital millennium. However our study has only just begun. There are several bills still on Congress's agenda. The DMCA is composed of complex rules and regulations and will face heavy testing in courts around the nation. It is too early to tell how these battles will affect educators. Perhaps amendments or further statutory interpretations will be necessary by the federal legislature in order to alleviate these concerns. Among the problems is that the fair use provision, as applicable to the electronic age, is not clearly understandable within the new law.

However, if educators are to advance in the digital age, they must cut a compromise between right and rule, between freethinking and structured regulation. It will be a test of time as to whether or not the Clinton administration's efforts will be a cure or a curse for the new 
millenium in copyright. The only way to examine The DMCA's validity is by trial and error. Unfortunately all of us involved with copyright may be cursed with many of each.

\section{ABOUT THE AUTHOR}

Dr. Robert N. Diotalevi is Director of Legal Studies and Associate Professor at The College of West Virginia. He has been a lawyer for fourteen years. He possesses four degrees and has been internationally published. He serves as an editor on The Online Journal of Distance Learning Administration. He has developed two web-based courses, The Law of Cyberspace and Copyright Law. Dr. Diotalevi is co-authoring a book entitled, The ETD's Sourcebook: Theses and Dissertations in the Electronic Age, which Scarecrow Press will publish this year.

\section{REFERENCES}

1. ACLU v. Reno, 929 F. Supp.824 (E.D. Pa. 1996).

2. Templeton, Brad, Ten Big Myths about Copyright Explained, http://www.clari.net/brad/copymyths.html (accessed February 17, 1999).

3. Litman, Jessica, The Exclusive Right to Read, 13 Cardozo Arts \& Ent. L.J. 29, at 50-51 (1994). http://www.msen.com/ litman/read.htm.

4. Schlachter, Eric, The Intellectual Property Renaissance in Cyberspace; Why Copyright Law Could be Unimportant on the Internet, 12 BERKELEY TECH. L.J. 1, Spring 1997.

5. Crews, Kenneth D., Copyright Law, Libraries and Universities: Working Paper, http://palimpsest.stanford.edu/bytopic/intprop/crews.html (accessed February 17, 1999).

6. Copyright Basics, available from the U.S. Government, http://lcweb.loc/gov/copyright/cirs/circ01.html (accessed February17, 1999).

7. 17 U.S.C. $\$ 101$ et seq. (1994).

8. 17 U.S.C. $\$ 106$ (1994).

9. http://lcweb.loc.gov/copyright/circs01.html.

10. 17 U.S.C.A $\S 102(a)(1996)$.

11. Feist Publications, Inc. v. Rural Tel. Ser. Co., 499 U.S. 340, 349-50 (1991), http://www.seamless.com/rcl/feist.html (accessed February 1, 1999).

12. Thorner, Benjamin B., Copyright Protection for Computer Databases: The Threat of Feist and a Proposed Solution, 1 VA. J.L. \& TECH. 5, Spring 1997, http://scs.student.virginia.edu/ vjolt/graphics/vol1/home art5.html.

13. 17 U.S.C.A. $§ 102$ (a) (West 1996).

14. The U.S. Copyright Website, http://lcweb.loc.gov/copyright/circs/circ01.html (accessed Jan. 1,1999).

15. Radcliffe, Mark F., The Law of Cyberspace for Non-Lawyers, The Cyberspace Law Primer, October 1996, http://www.gcwf.com/articles/primer.htm.

16. 17 U.S.C.A. § 101 (1996).

17. 17 U.S.C.A. § 301 (1996).

18. United States Department of Commerce, Information Infrastructure Task Force, Intellectual Property and the National Information Infrastructure: The Report of the Working Group on Intellectual Property 10-11 (1995) (known as the White Paper), Office of Legislative and International Affairs, U.S. Patent and Trademark Office, Box 4, Washington, D.C. 20231, http://www.uspto.gov/web/offices/com/doc/ipnii.

19. Cover, Kathi A., The Emperor's Magic Suit: Proposed Legislation Will Tailor the Copyright Law to Fit the Internet, http://www.smu.edu/ csr/win96a2.htm (accessed Jan.17, 1999).

20. 17 U.S.C. $\S \S 408$ and 409. The United States Copyright Office: Phone: 202-707-3000 (person); Phone: 202-707-9100 (publications); Fax: 202-707-2600; E-mail: LISTSERV@RS8.loc.gov. To subscribe to 
the Newsnet Issue services, put "Subscribe US Copyright" in the body of the message; Web: http://lcweb.loc.gov/copyright.

21. Field, Thomas G, Copyright for Computer Authors, Franklin Pierce Law Center, http://www.fplc.edu/tfield/copySof.htm (accessed Jan. 20, 1999).

22. 17 U.S.C. $\$ 302$.

23. 17 U.S.C. $\S 2589$.

24. Berne Convention Implementation Act of 1988, Pub. L. No. 100-568, 102 Stat. 2853 (codified in 17 U.S.C.A. § 101 (West 1996)).

25. 17 U.S.C. $\S 107$ (1992).

26. 510 U.S. 569 (1994).

27. Circular 21 (p. 8), Reproduction of Copyrighted Works by Educators and Librarians, U.S. Government Printing Office, Washington, D.C., 1995.

28. 510 U.S. 569, 114 S. Ct. 1164(1994) at 1174-1179 and 578 n. 10.

29. http://supct.law.cornell.edu/supct/html/92-1292.ZO.html.

30. Besek, June M., The Evolving Law of Copyright and the Internet: Recent Developments in Fair Use Under the Copyright Act, http://cla.org/matsnpubs/memberarticles/evolve.htm (accessed December 1, 1998).

31. Crews, Kenneth D., Copyright and Distance Education: Lawful Uses of Protected Works, http://www.ihets.org/distance_ed/ipse/fdhandbook/copyrt.html (accessed November 16, 1998).

32. 758 F. Supp. 1522 (S.D. N.Y. 1991).

33. 60 F. 3d 913 and 916 (2d Cir.1994).

34. CONFU's draft report: http://uspto.gov/web/offices/dcom/olia/confu/report.htm.

35. 99 F. 3d 1381 and at 1393 (6 $6^{\text {th }}$ Cir. 1996).

36. http://www.utsystems.edu/OGC/intellectualproperty/distguid.htm.

37. John Marshall University Law School, http://www.jmls.edu/cyber/others.html (accessed May 1, 1999).

38. Yale University, http://library.yale.edu/\%7Eokerson/copyproj.html (accessed May 2, 1999).

39. "Guidelines for Creating a Policy for Copyright Compliance," contact Copyright Clearance Center, 222 Rosewood Drive, Danvers, MA 01923; phone: 781-239-0057; http://www.copyright.com.

40. http://www.loc.gov/copyright/title17/chapter1.pdf.

41. 907 F. Supp.1361 and 1374 (N.D. Cal. 1995).

42. 923 F. Supp. 1231 (N.D. Cal. 1995).

43. 839 F. Supp. 1552 (M.D. Fla. 1993).

44. 907 F. Supp. 1372-73.

45. http://www.jmls.edu/cyber/cases/netcom.txt.

46. Hayes, David L., Application of Copyright Rights to Specific Acts on the Internet, 15 NO. 8 , Computer Law 1, August, 1998.

47. Burcher, Eugene A. and Hughes, Anna M., Casenote, Religious Tech. Ctr. v. Netcom On-Line Communications, Inc.: Internet Service Providers: The Knowledge Standard for Contributory Copyright Infringement and The Fair Use Defense, 3 RICH. J.L. TECH. 5, 1997, http://www.richmond.edu/jolt/v3i1/burhugh.html.

48. 17 U.S.C. $\$ \S 504-506$.

49. U.S.C. Title $18 \S 2319$ (b).

50. Circular 21, p. 26.

51. Bruce, G. and Vogel, David A., Copyright Protection of Software and Compilations: A Review of Critical Developments, Advanced Seminar on Copyright Law, 441 PLI/PAT, p. 382, May 19,1999.

52. ProCD, Inc. v. Zeidenberg, 86 F. 3d 1447, 1449, $7^{\text {th }}$ Cir. 1996.

53. Hawkins, Jennifer L., ProCD v. Zeidenberg: Enforceability of Shrinkwrap Licenses Under the Copyright Act, 3 RICH. J.L. \& TECH. 6, 1997, http://www.richmond.edu jolt/v3il/hawkins.html.

54. The Copyright WebSite, http://www.benedict.com/webiss.htm (accessed February12 1999).

55. http://www.patents.com/weblaw.sht.

56. Pub. L. No. 105-304, 112 Stat. 2860.

57. H.R. 2281 in the House of Representatives, and S. 2037 in the Senate (S. 1121, abandoned with the passage of this legislation).

58. http://lcweb.loc.gov/copyright/legislation/hr2281.pdf (accessed February 1, 1999).

59. http://lcweb.loc.gov/copyright/legislation/dmca.pdf (accessed February 1, 1999). 
60. http://lcweb.loc.gov/copyright/disted/ (accessed February 1, 1999).

61. Radcliffe, Mark, The Digital Millennium Copyright Act, http://www.gcwf.com/articles/interest/interest11.html.

62. The Digital Future Coalition, http://www.dfc.org (accessed Dec. 31, 1998).

63. Statement by the President, Office of the President's Press Secretary, The White House, October 12, 1998, ftp://ftp.aimnet.com/pub/users/carroll/law/copyright/h2281- res.txt.

64. Now Public Law No: 105-304.

65. http://thomas.loc.gov.

66. http://www.dfc.org/issues/graphic/2281/2281.html (accessed February 6, 1999).

67. The Software Publishers Association, http://www.spa.org/govmnt/iprt/dmcasumdraft.htm (accessed February 7,1999).

68. Oman, Ralph, New Global Treaties Protect Copyrights Online, Law Journal Extra, http://www.ljx.com/copyright/p4global.html (accessed February 17, 1999).

69. Liebowitz, Wendy, Lawyers and Technology: The Sound of One Computer Copy, Law Journal extra, citing The National Law Journal), p. A16, November 2, 1998, http://www.ljx.com/news/dime.htm.

70. American Library Association News and Views, June 10, 1998, http://www.ala.org/news/copyright.html.

71. Press release, Association of Research Libraries, Washington, D.C., Sept. 29, 1998, http://arl.cni.org.

72. Digital Future Coalition, http://ari.net/dfc/issues/wipo/pr101698/pr101698.html (accessed October 16, 1998).

73. The Digital Millennium Copyright Act of 1998, U.S. Copyright Office Summary, http://lcweb.loc.gov/copyright/legislation/dmca.pdf (accessed May 13, 1999).

74. Report on Copyright and Digital Distance Education (see xv, 146, 154-159), U.S. Copyright Office, May 26, 1999, http://lcweb.loc.gov/copyright/disted.

75. Mendels, Pamela, U.S. Copyright Proposal Supports Distance Learning, New York Times, May 29, 1999.

76. McCollum, Kelly, Copyright Office Releases Proposal for On-Line Distance Education, The Chronicle of Higher Education, Vol. XLV, No. 41, June 18, 1999.

77. http://www.spa.org/govmnt/iprt/wipotalk.htm.

78. U.S. Copyright Office Newsnet Issue 47, U.S.Copyright Office NewsNet, May 18, 1999, http://thomas.loc.gov/cgi-bin/query/C?c106:/temp/ c106DDXM97.

79. Macavinta, Courtney, Digital Copyright Bill Becomes Law, CNET NEWS.com, October 28, 1998, http://www.news.com/News/Item/0,4,28060,00.html?owv.

80. 17 U.S.C. $\S \S 1204$ a \& b.

81. http://spa.org/govmnt/iprt/wipotalk.htm.

82. 17 U.S.C. $\$ 1201(b)$.

83. Discussion Draft on Copyright Considerations for Faculty Authored Multimedia Course Materials, The University of California Committee on Intercampus Information Technology and Networking for Academic Purposes (CINITAP), 1996, http://www.ucop.edu/irc/wp/wp_Docs/wpd002.html (accessed May 16, 1999).

84. Band, Jonathan, The Digital Millennium Copyright Act, http://www.dfc.org/issues/wipo/graphic/2281/JB-index/jb-index.html (accessed Dec. 1, 1999). 